\title{
Variation in the pith parameter of Gmelina arborea trees from fast growth plantations in Costa Rica
}

\author{
Róger MOYA*, Liz ARAYA, Braulio VILCHEZ \\ Escuela de Ingeniería Forestal, Instituto Tecnológico de Costa Rica, Apartado 159-7050, Cartago, Costa Rica
}

(Received 13 November 2007; accepted 5 June 2008)

\begin{abstract}
-
- The pith represents the central part of the cross-section of a tree trunk and it is composed of primary parenchyma tissue. And its eccentricity is associated with the presence of reaction wood, which affects trunk straightness, and diminishes the quality of the logs and products.

- Gmelina arborea trees (8 to 14 years old) from fast growth plantations in Costa Rica were sampled with the purpose of determining diameter, eccentricity and pith percentage as well as pith distance from the real centre of the cross section. These pith parameters were also evaluated in relation to management intensity (intensive, moderate and unmanaged), climate (dry and wet tropical) and tree height.

- Pith diameter varies from 0.15 to $1.10 \mathrm{~cm}$ and is located at $6 \mathrm{~cm}$, at its maximum, around the real centre of the cross section. Percentage eccentricity might reach values of up to $26.5 \%$ and this parenchyma tissue represents between 1 and $5 \%$ of the total tree diameter.

- The level of management had a significant effect on the eccentricity and percentage of the pith, while the climate significantly affected the pith percentage and the distance of pith from the real centre of the cross section. Tree height affected significantly all the parameters evaluated.
\end{abstract}

stem eccentricity / pith percentage / stem form / lumber quality

Résumé - Variation des caractéristiques de la moelle des arbres de Gmelina arborea issus de plantations à croissance rapide au Costa Rica. - La moelle représente la partie centrale sur la coupe transversale d'un tronc d'arbre et elle est composée de tissus de parenchyme primaire. La moelle est associée à la présence de bois de réaction, qui affecte la rectitude du tronc, et diminue la qualité des billes de bois et des produits provenant de celles-ci.

- Des arbres de Gmelina arborea (âgés de 10 à 12 ans) issus de plantations à croissance rapide au Costa Rica ont été récoltés et étudiés dans le but de déterminer le diamètre, l'excentricité, le pourcentage de moelle, de même que la distance de la moelle au centre réel de la section transversale. Ces caractéristiques de la moelle furent aussi évaluées par rapport au type d'aménagement forestier pratiqué sur ces plantations (intensif, modéré et non aménagé), au climat (tropical sec et humide) et à la hauteur des arbres.

- Le diamètre de la moelle varie entre 0,15 et $1,10 \mathrm{~cm}$ et se trouve à $6 \mathrm{~cm}$, à son maximum, du centre réel de la section transversale. Le pourcentage d'excentricité pourrait atteindre jusqu'à $26,5 \%$ et les tissus parenchymateux représentent entre 1 et $5 \%$ du diamètre total de l'arbre.

- Le niveau d'aménagement forestier a eu un effet significatif sur l'excentricité et sur le pourcentage de moelle, alors que le type de climat a significativement affecté le pourcentage de moelle et la distance de la moelle au centre réel de la section transversale. La hauteur des arbres a, quant à elle, influé de façon significative sur tous les paramètres étudiés.

excentricité de la tige / pourcentage de la moelle / forme de la tige / qualité du bois

\section{INTRODUCTION}

Gmelina arborea has been successfully introduced to many countries in the tropical regions of America, Asia and Africa, with the purpose of producing raw material for cellulose production, sawlogs or biomass for energetic purposes (Dvorak, 2004). In Costa Rica, Central America, this species has been used in reforestation to produce sawlogs for the civil construction market and furniture manufacture (Moya, 2004a).

In spite of the good results, there are often problems with the industrial sawing of logs from fast growth plantations. These are associated with the presence of reaction wood and large pith eccentricity, both of which decrease log and lumber quality (Constant et al., 2003; Lundgren, 2000; Moya and Muñoz, 2008).

*Corresponding author: rmoya@itcr.ac.cr
The pith is located in the center of the cross-section and it is composed of primary parenchyma tissue formed by the apical meristem at the growing tip (Akachuku and Abolarin, 1989). It has limited physiological function during growth, but its importance in the storage of the physiological residue of the metabolic processes of the tree has been suggested (Jane et al., 1970). In Gmelina arborea, this fundamental tissue has its origin in the internal part of the central trunk, composed of parenchyma cells, and it developed during meristem stage (Albert and Shah, 1998).

There are many studies that relate variations in the pith patterns to the presence of reaction wood and to the straightness of the tree trunk. Reaction wood is generated to contribute to improve the performance of the re-orientation mechanism (Clair et al., 2006). In the industrial utilization of the log, these factors diminish both the amount and quality of log products 
that can be obtained from the wood (Cassens, 2004; Timell, 1986).

For some softwood species, Williamson (1975), Kellog and Barber (1981), Rune and Warensjö (2002), Singleton et al. (2003), and Warensjö and Rune (2004) found that the main causes of pith variation are plantation density, tree height and diameter, the way the plantation is managed, tree age, site quality, growth rate and crown size. For hardwood species, pith variation is affected by site, tree height, topography and some environmental conditions (Akachuku and Abolarin, 1989; Kucera and Philipson, 1977).

To examine the influence of pith on the quality of wood and end-products, and to establish the importance of Gmelina in reforestation processes in Costa Rica, the following objectives were addressed: (1) Describe the variation in the patterns of pith for Gmelina arborea trees growing in forest plantations. (2) Evaluate the effect of plantation management, climate and tree height on: the diameter of pith, percentage and eccentricity of the pith, and the distance from the geometric center to the pith.

\section{MATERIALS AND METHODS}

\subsection{Areas sampled}

Fifty eight Gmelina plantations distributed across Costa Rica and its two different climates were chosen (Fig. 1). The climate types were: (i) wet tropical, characterized by a mean annual precipitation of $3000-5000 \mathrm{~mm}$ with temperatures of $20-25{ }^{\circ} \mathrm{C}$, and a moderate dry season lasting 3 months (January-March) with rainfall decreasing from 450 to $70 \mathrm{~mm} / \mathrm{month}$, and (ii) dry tropical, with a mean annual precipitation of $1500-2000 \mathrm{~mm}$ and temperatures of $25-28{ }^{\circ} \mathrm{C}$ with a period of severe drought (January-March) with virtually $0 \mathrm{~mm}$ rainfall/month.

\subsection{Silvicultural regimes}

Preliminary inspections were carried out on many G. arborea plantations in each zone and these were classified as being under one of three different management regimes (unmanaged, moderate management and intensive management). For each type of management regime, in each of the two climates of Costa Rica, ten 8- to 14-yearold fast growth plantations were selected (Fig. 1), for a total of 58 different sites. From each of these, one tree was selected for sampling. The initial density, silvicultural treatments, age and density at sampling time for each category are detailed in Tables I and II.

\subsection{Plots and tree selection}

Eight- to 13-year-old plantations were sampled and their geographic location determined using a global positioning system (GPS). One plot $\left(400 \mathrm{~m}^{2}\right)$ was established in each of the plantations to be sampled. The topography was almost flat or gently undulating. Diameter at breast height (DBH), total and crown length, density of plantation, and management type, were measured in each plot (Tab. II).

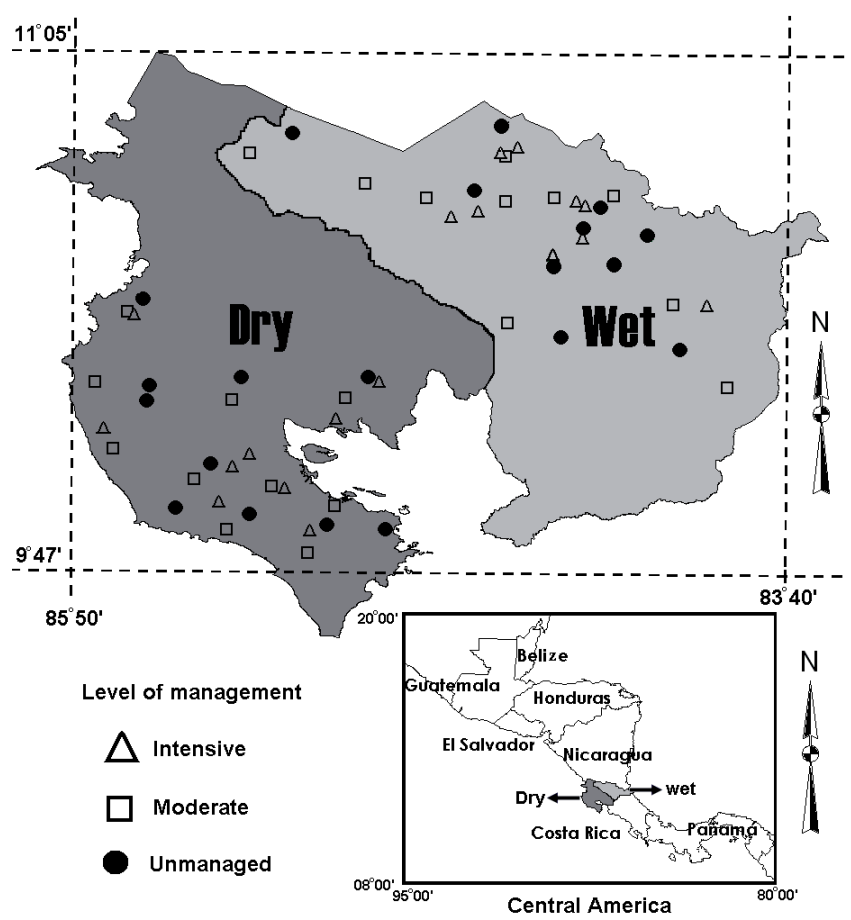

Figure 1. Location of the plantations sampled under two tropical climatic conditions in Costa Rica.

\subsection{Tree sampling in the plantations}

In each plantation, one tree with an average $\mathrm{DBH}$, a straight trunk, normal branching, and no disease or pest symptoms was felled. North was marked on each sampled tree. From each of these trees, stem discs were cut at $0,1.25,2.50,3.75,5.00,6.25,7.50,8.75$, $10.00,11.25,12.50,13.75,15.00,16.25$ and $17.50 \mathrm{~m}$ of the tree's height. The cardinal directions were again marked on the sampled discs. Some discs were eliminated because they were sampled near to branch or fungi attack was presented. Number of discs was not consistent for each tree or each situation because trees height was not homogeneous (Tab. II). The total sampled discs were 604, where 96 discs were for intensive, 103 for moderate and 87 for unmanaged in dry climate (286 discs for this climate conditions) and 318 discs were for wet climate with 99 for intensive, 111 for moderate and 108 for unmanaged.

\subsection{Pith parameter determination}

Discs with splitting and distortion were eliminated and parameters were measured using green material. On each disc, a cross-sectional line was drawn from north to south passing through the pith and another was marked perpendicular to the first, from east to west (Fig. 2). $P$ ith diameter and total diameter including the bark were measured in both directions. Pith diameter was averaged from two measurements and percentage pith was calculated using the formula: pith percentage $=$ pith diameter $\times$ total diameter ${ }^{-1} \times 100$.

The pith eccentricity index and the distance of the pith from the geometric center were determined using the procedure that Akachuku and Abolarin (1989) applied to Tectona grandis. The circles of several diameters were traced on a transparent sheet of polyethylene. 
Table I. Characteristics of the levels of management used on Gmelina arborea tree plantations in Costa Rica in this study.

\begin{tabular}{|c|c|}
\hline Type of management & Silvicultural treatment \\
\hline Unmanaged & $\begin{array}{l}\text { Initial density was } 1100 \text { trees }^{\text {ha }} \mathrm{a}^{-1}(3 \times 3 \mathrm{~m} \text { spacing }) \text {; silvicultural activities (thinning and pruning) were not carried } \\
\text { out. Death was natural and branches fell off some trees. Plantation density was more than } 800 \text { trees }^{-1} \mathrm{ha}^{-1} \text { at the time of } \\
\text { sampling. }\end{array}$ \\
\hline Moderate & $\begin{array}{l}\text { Initial density was } 1100 \text { trees ha }^{-1}(3 \times 3 \mathrm{~m} \text { of spacing }) \text {, and selective thinning was applied to trees } 4 \text { to } 6 \text { years old with } \\
\text { pruning at } 50 \% \text { of total height of the tree. Plantation density was } 350 \text { to } 700 \text { trees ha }^{-1} \text { at the time of sampling. }\end{array}$ \\
\hline Intensive & $\begin{array}{l}\text { Initial density was } 1100 \text { trees ha } \mathrm{h}^{-1} \text { ( } 3 \times 3 \mathrm{~m} \text { of spacing). The application of a first selective thinning was } 30-40 \% \text { when } \\
\text { trees were } 3 \text { to } 4 \text { years old. There was a second thinning of } 40-50 \% \text { at } 6 \text { to } 7 \text { years old and a third thinning of } 30-40 \% \\
\text { between } 8 \text { and } 9 \text { years old. The pruning was of } 50 \% \text { intensity at the same age for the first and second thinning. For } \\
\text { the third thinning, pruning was applied up to } 7 \mathrm{~m} \text { of the tree's height. The density at the time of sampling was } 170 \text { to } \\
350 \text { trees ha }{ }^{-1} \text {. }\end{array}$ \\
\hline
\end{tabular}

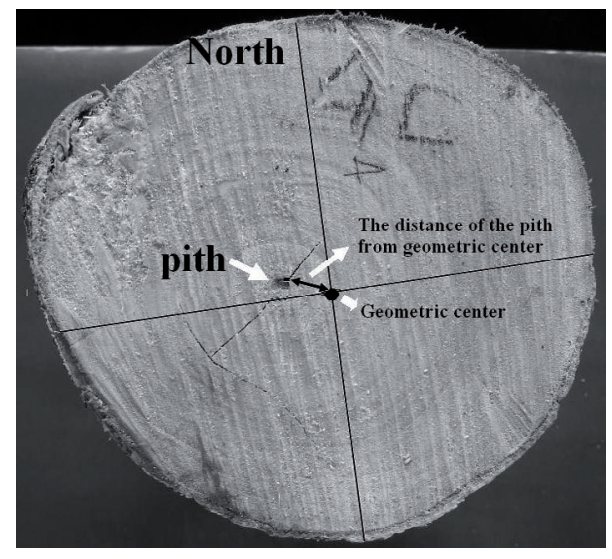

Figure 2. Transverse stem disc of Gmelina arborea.

The sheet was collocated on discs. The traces of fluted discs were superimposed on the nearest circles and geometric center was marked (Fig. 2). The geometric center of a disc was the point of intersection between the longer and shorter diameters. The pith distance from geometric center represents the distance between the pith and geometric center marked within its traced circumference. There was considered that pith occurs in the geometric center when distance was less than $5 \mathrm{~mm}$. The distance between the pith and geometric center of the cross-section expressed as a percentage of the disc's mean radius was defined as pith eccentricity.

\subsection{Statistical analysis}

It was necessary to transform all pith parameters in order to carry out the statistical analyses. Square root transformations were applied to pith diameter and distance from the geometric center. A logarithmic transformation was applied to pith eccentricity and 0.3 exponential coefficients were used for pith percentage (Tab. III). These transformations were necessary because the parameters did not meet the assumptions of normal distributions (Snepthorne and Cochran, 1980). An analysis of variance (ANOVA) was used to test the effect of the management regimes, climatic conditions, tree height, and their interactions on pith parameters. Regression analysis was used to assess the relationship between the height on the tree from which the sample was taken and each of the following parameters: pith diameter, pith distance from geometric center and pith eccentricity. These relationships were applied when the interactions were not significant. The number of times that the pith occurs in the geometric center of the disc was evaluated for each tree height and a regression analysis was applied to demonstrate the changes with height.

\section{RESULTS AND DISCUSSION}

\subsection{Pith diameter}

Pith diameter in G. arborea, ranges from 0.15 to $1.10 \mathrm{~cm}$. The sampling height factor and the interactions between management regime and climate were the main factors that contributed to the increase in pith diameter (Tab. II). However, this interaction was not significant. In fact, on testing for any differences between the two types of climates in the management regimes, it was not possible to detect any statistically significant differences (Fig. 3a). Lower down on the tree, the pith diameter was lowest. Pith diameter increased with increasing tree height, from the base up to $5 \mathrm{~m}$ high. Above this, diameter decreased slightly until $12.5 \mathrm{~m}$, afterwards it increased slightly (Fig. 3b).

Pith diameter has received little attention, probably because variations in pith eccentricity inside the tree are considered to be the most limiting factors with respect to industrial use. Nevertheless, the values obtained for pith diameter in lumber may result in very big cups along the board and in turn, rejection of the board during its classification for a specific use, as would occur with the structural classification used in North America (ASTM, 2003). On the other hand, the results for variation in pith diameter suggest that during the first years of growth, the quantity of cells or the size of cells in the procambial stage and the petiole is lower than when a tree is taller and older; even more so, when it reaches a height over $5 \mathrm{~m}$ (Fig. 3b), where larger pith diameters were recorded. Second hypothesis can be considered, growth stress is present in tree age and it increased with increasing of tree diameter (Archer, 1986) producing high compression at pith to neutral. This force may result a reductions in pith diameter with tree age, especially in lower part of trees. Another factor worth mentioning is that the diameter of this tree tissue is stable across climate conditions and type of management, though there was a slight interaction between 
Table II. Geographical location and description of the sampled plantations in two different climates in Costa Rica.

\begin{tabular}{|c|c|c|c|c|c|c|c|}
\hline$\overline{\text { Zone }}$ & $\begin{array}{c}\text { Level of } \\
\text { management }\end{array}$ & $\begin{array}{c}\text { Tree } \\
\text { number }\end{array}$ & $\begin{array}{c}\text { Tree age } \\
\text { (years) }\end{array}$ & $\begin{array}{l}\text { Diameter at breast height } \\
\qquad(\mathrm{cm})\end{array}$ & $\begin{array}{l}\text { Total height } \\
\text { (m) }\end{array}$ & $\begin{array}{l}\text { Crown length } \\
(\mathrm{m})\end{array}$ & $\begin{array}{l}\text { Density of plantation } \\
\qquad\left(\mathrm{n} \mathrm{ha}^{-1}\right)\end{array}$ \\
\hline \multirow{29}{*}{ Dry tropical } & \multirow{10}{*}{ Unmanaged } & 1 & 10 & 20.50 & 18.70 & 13.00 & 827 \\
\hline & & 2 & 9 & 18.80 & 10.40 & 5.00 & 796 \\
\hline & & 3 & 9 & 18.80 & 19.00 & 9.50 & 732 \\
\hline & & 4 & 10 & 22.50 & 22.10 & 1420 & 636 \\
\hline & & 5 & 11 & 18.00 & 17.50 & 11.00 & 859 \\
\hline & & 6 & 13 & 20.70 & 18.30 & 9.10 & 796 \\
\hline & & 7 & 12 & 20.10 & 20.30 & 13.20 & 764 \\
\hline & & 8 & 12 & 2150 & 21.30 & 15.40 & 668 \\
\hline & & 9 & 9 & 2300 & 21.00 & 13.10 & 605 \\
\hline & & 10 & 9 & 20.20 & 22.00 & 13.00 & 732 \\
\hline & \multirow{10}{*}{ Moderate } & 1 & 8 & 25.50 & 22.00 & 16.70 & 509 \\
\hline & & 2 & 8 & 19.70 & 19.50 & 13.20 & 509 \\
\hline & & 3 & 10 & 26.40 & 18.50 & 12.65 & 541 \\
\hline & & 4 & 9 & 22.50 & 23.30 & 13.40 & 477 \\
\hline & & 5 & 9 & 23.40 & 17.80 & 13.50 & 477 \\
\hline & & 6 & 10 & 26.00 & 21.00 & 13.80 & 573 \\
\hline & & 7 & 12 & 24.00 & 24.70 & 14.60 & 573 \\
\hline & & 8 & 10 & 23.50 & 18.50 & 7.70 & 605 \\
\hline & & 9 & 9 & 2380 & 2020 & 10.10 & 541 \\
\hline & & 10 & 12 & 23.90 & 2210 & 1510 & 509 \\
\hline & \multirow{9}{*}{ Intensive } & 1 & 10 & 29.90 & 20.80 & 11.00 & 318 \\
\hline & & 2 & 11 & 31.90 & 16.50 & 10.00 & 95 \\
\hline & & 3 & 10 & 26.80 & 19.50 & 12.50 & 318 \\
\hline & & 4 & 14 & 32.50 & 24.70 & 13.50 & 350 \\
\hline & & 5 & 12 & 31.50 & 18.90 & 7.40 & 223 \\
\hline & & 6 & 13 & 26.80 & 2700 & 17.30 & 382 \\
\hline & & 7 & 10 & 29.00 & 24.00 & 1100 & 350 \\
\hline & & 8 & 9 & 3150 & 26.66 & 14.50 & 286 \\
\hline & & 9 & 12 & 3320 & 27.10 & 17.10 & 350 \\
\hline \multirow{29}{*}{ Wet tropical } & \multirow{10}{*}{ Unmanaged } & 1 & 8 & 24.00 & 21.80 & 15.00 & 732 \\
\hline & & 2 & 8 & 21.50 & 21.50 & 17.50 & 1082 \\
\hline & & 3 & 8 & 21.90 & 17.40 & 8.50 & 859 \\
\hline & & 4 & 11 & 21.00 & 19.10 & 11.60 & 764 \\
\hline & & 5 & 11 & 21.00 & 21.00 & 17.30 & 732 \\
\hline & & 6 & 9 & 24.10 & 15.00 & 12.00 & 891 \\
\hline & & 7 & 11 & 24.35 & 20.00 & 13.80 & 1496 \\
\hline & & 8 & 11 & 26.70 & 25.76 & 20.50 & 637 \\
\hline & & 9 & 10 & 22.10 & 17.70 & 10.00 & 923 \\
\hline & & 10 & 11 & 26.00 & 23.50 & 13.50 & 891 \\
\hline & \multirow{10}{*}{ Moderate } & 1 & 8 & 25.00 & 19.00 & 6.00 & 459 \\
\hline & & 2 & 9 & 27.00 & 14.40 & 6.60 & 382 \\
\hline & & 3 & 8 & 23.90 & 19.00 & 8.50 & 382 \\
\hline & & 4 & 8 & 28.50 & 22.50 & 14.00 & 477 \\
\hline & & 5 & 8 & 26.00 & 25.00 & 18.00 & 477 \\
\hline & & 6 & 9 & 25.02 & 21.40 & 14.00 & 350 \\
\hline & & 7 & 9 & 24.50 & 20.20 & 10.70 & 318 \\
\hline & & 8 & 8 & 30.00 & 23.20 & 16.00 & 446 \\
\hline & & 9 & 8 & 28.30 & 24.00 & 14.30 & 414 \\
\hline & & 10 & 10 & 28.30 & 24.00 & 18.00 & 605 \\
\hline & \multirow{9}{*}{ Intensive } & 1 & 8 & 38.00 & 15.50 & 11.00 & 159 \\
\hline & & 2 & 9 & 31.50 & 22.00 & 11.00 & 318 \\
\hline & & 3 & 12 & 31.80 & 24.00 & 15.00 & 223 \\
\hline & & 4 & 10 & 33.20 & 18.50 & 11.20 & 191 \\
\hline & & 5 & 9 & 32.00 & 23.50 & 14.50 & 223 \\
\hline & & 6 & 8 & 30.50 & 17.00 & 11.30 & 223 \\
\hline & & 7 & 8 & 32.00 & 25.00 & 13.50 & 223 \\
\hline & & 8 & 8 & 32.50 & 23.70 & 17.00 & 223 \\
\hline & & 9 & 8 & 30.70 & 18.00 & 13.00 & 127 \\
\hline
\end{tabular}


Table III. Analysis of variance of pith parameters in Gmelina arborea trees from fast growth plantations.

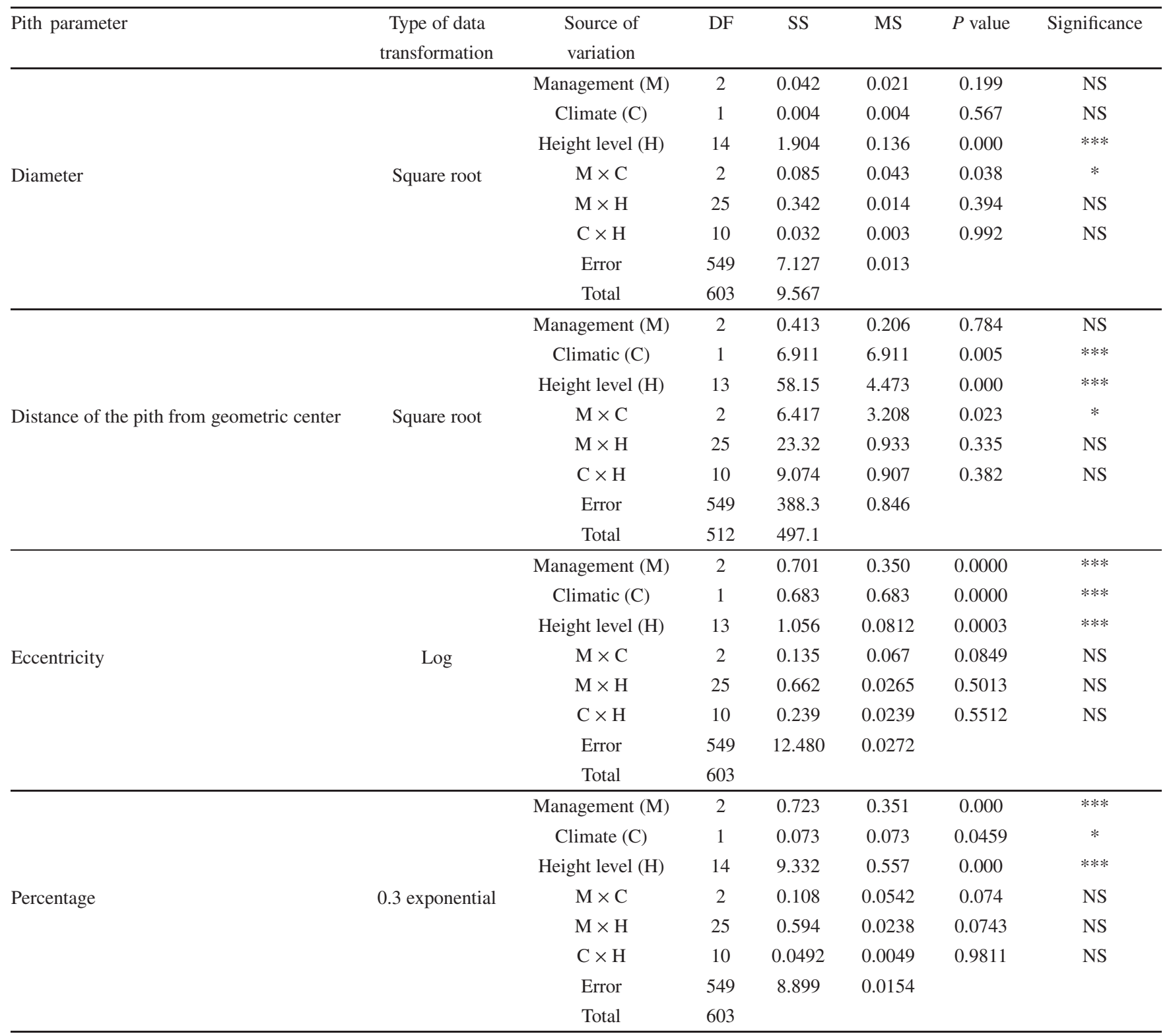

NS: Not significant; *** highly significant $(\alpha=0.01)$; * significant $(\alpha=0.05)$.

these two factors that was not significant (Tab. III). These results suggest that pith diameter has ontogenetic trend and can be controlled by factors such as biological, physiological or genetic factors during the formation of primary parenchyma tissue in the procambial zone (Mikesell et al., 1980) or conditions where trees growth such as competition, site, management or high growth stresses presence.

\subsection{Distance of the pith from geometric center}

Figure $4 \mathrm{a}$ shows that the pith was located $6 \mathrm{~cm}$ around the geometric center; however, it was found to decrease with tree height (Fig. 4c). It was observed that the quantity of time that pith occurred proximately in the geometric center of the disc (distance less than $5 \mathrm{~mm}$ ) increased at a constant rate with increasing height (Fig. 4b). As a result, we can say that the pith is not located on the geometric center of the disc, although there is a tendency for the pith to be in center of cross-section with tree height (Fig. 4c). The findings of Singleton et al. (2003) for Tsuga heterophylla agree with our results, however, small differences were also found, because the pith distance from geometric center remained relatively constant in the upper two thirds of the bole in T. heterophylla.

The large pith distance from geometric center affects the accuracy of predicting tree features, plantation attributes, 

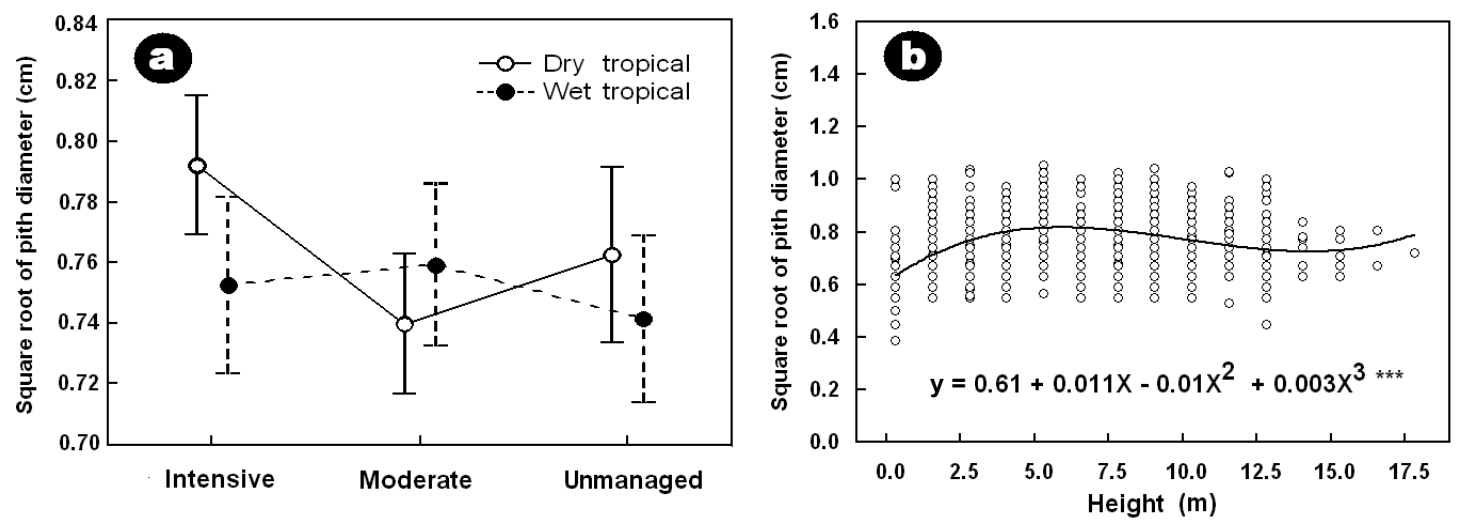

Figure 3. (a) Mean and $95 \%$ confidence limits of pith diameter for different management regimes and climates and (b) variation in pith diameter with tree height level.
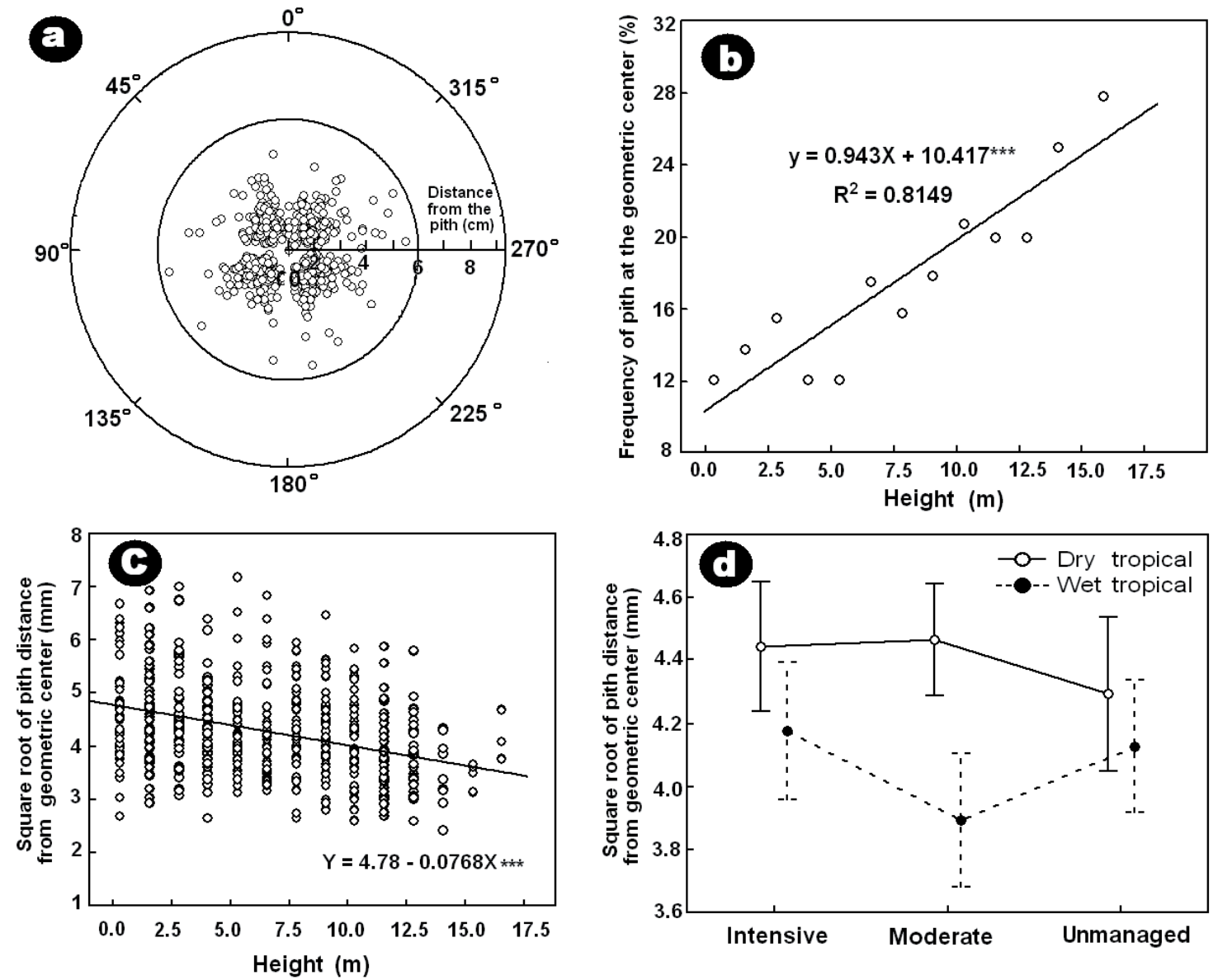

Figure 4. Location of pith in cross section for all discs (a), number of time that pith in the geometric center of tree (b), variation of pith distance from geometric center along tree height (c), and effect of climate condition and management intensity on pith distance from geometric center (d) in Gmelina arborea trees on a fast growth plantation in Costa Rica. 
sawmill processes and lumber quality (Cassens, 2004). For example, the location of the pith could be associated with the presence of juvenile wood or reaction wood (Koch et al., 1990, Saint-André and Leban, 2001; Singleton et al., 2003; Timell, 1986). In the first case, the occurrence of the pith in the lowest part of the bole in Tsuga heterophylla (western hemlock) trees was correlated with the presence of a juvenile core (Singleton et al., 2003). This was confirmed on the plantations sampled in our research, where trees were less than 12 years old. The determination of wood density, fiber dimension and mechanical wood properties for the same trees confirm the presence of juvenile wood (Moya, 2004b; Moya and Tomazello, 2007a; 2007b).

Logs from the lower part of the tree in which the pith was far away from the geometric center create many problems in processing and product performance because they may yield boards of greater proportions with pith tissue, than logs with centered pith would (i.e. from the tallest trees). This could decrease grade recovery and profit since the grade of a given piece is limited by the portion with the poorest quality. Unfortunately, this part of the $\log$ is also the largest and potentially provides the products that are highest in value.

Variations in pith distance were significantly affected by climate. In general, the distance from the pith to the geometric center in trees from plantations in the tropical dry climate was greater than that of trees from plantations in the tropical wet climate; however, this difference was only statistically verified for the moderate management regime (Fig. 4d). These results verify the interaction between the level of management and climate type revealed by the ANOVA (Tab. III). The differences recorded for the different levels of management and climate conditions, suggest that pith distance and the geometric center of the tree, are regulated by factors that were not considered in this stud, such as growth dynamics (Cremer, 1998). Singleton et al. (2003), after a large study on pith variation, concluded that the relationships between pith occurrence and tree height could be influenced by plantation density, stand age, site class, crown ratio, growth rate and other important factors such as tree lean, slope or wind. The lack of a significant difference was probably the result of sampled trees occurring in different climatic conditions, geographical positions, level of management, and slightly different terrains and stand densities. Additionally, crown length and crown shape, as well as unevenness in the distribution of the crown around the bole of each tree were all different for all the trees sampled (Tab. II).

\subsection{Eccentricity of pith}

Pith eccentricity exhibited variations of up to $26.5 \%$ and the ANOVA showed that it was significantly affected by the climatic region of Costa Rica, tree height and level of management (Tab. III). The interactions among these three factors were not statistically significant. The regression analyses show that pith eccentricity increased slightly with increasing height on the trees' boles. The increase was greater from the base up to a height of 7.5 to $10.0 \mathrm{~m}$, than it was above this height, where pith eccentricity was fairly constant (Fig. 5a).

At different stages of growth, the factors that made trees lean or bend varied. For example, a tree might bend uniquely at a certain height to get more light or avoid an obstacle and then straighten later. The influence leading to bending can vary considerably over the life of the tree (Akachuku, 1989). According to Kellog and Barber (1981), Gmelina arborea can be classified in the group of species for which there is a decrease in eccentricity with increasing height. The same change in pith eccentricity with increasing tree height has been reported for several species, among which Tectona grandis (Akachuku, 1989), Norway spruce (Saint-André and Leban, 2001), Pinus sylvestris (Warensjö and Rune, 2004), Tsuga heterophylla (Singleton et al., 2003) and several species of Populus are worth mentioning (Constant et al., 2003).

Pith distance tends to diminish with tree height (Fig. 4d) and the occurrence of pith in the geometrical centre of the tree increases with height (Fig. 4b). In contrast however, pith eccentricity tends to remain the same or increase along the tree's bole (Fig. 5a). According to the studies carried out on Pinus radiata by Cremer (1998), Little and Mergen (1966), and Manson (1985) this can be explained as follows. Although the pith has lost, at any moment of growth, its central position owing to the slope of the ground or effects external to the tree, occasionally the pith recovers its eccentricity somewhat, not only in the tree base but also in the part that is bearing the external forces.

Increasing the level of plantation management decreases pith eccentricity, not only in trees from wet tropical conditions, but also in those under dry tropical conditions (Fig. 5b). Saint-André and Leban (2001) have established that pith position is the result of the tree's growth history, including competition for light, soil fertility, the slope of the terrain where the stand is growing, and silvicultural treatment. Decreasing pith eccentricity with increasingly intense management is expected because during thinning, the twisted trees with bifurcations, those with little growth or with an undesirable shape are usually eliminated, leaving both the straight trees and those that have grown the most (Moya, 2004b). Furthermore, if there was eccentricity in the trees at the time of thinning, the greater radial increase in the tree of managed plantations decreases the pith's relative eccentricity as the tree's diameter increases (Saint-André and Leban, 2001).

Although the trees from plantations growing in a wet tropical climate show a tendency to decreased pith eccentricity, there was only a significant difference in the trees from plantations with moderate management (Fig. 5b). Wet tropical and dry regions receive different amounts of precipitation, and the direction and intensity of winds are different, as is the topography. Dry tropical areas are found in the northwestern part of Costa Rica where wind velocities are $12 \mathrm{~km} / \mathrm{h}$. December, January and March are the windiest months, while in April the average decreases to $5 \mathrm{~km} / \mathrm{h}$. Topography is irregular with differences in height of up to $100 \mathrm{~m}$. In contrast, the wet tropical region is located in the northern zone and is separated from the dry tropical by a mountain range reaching almost $2000 \mathrm{~m}$ asl. Average wind velocity is $5.5 \mathrm{~km} / \mathrm{h}$ and the topography is 

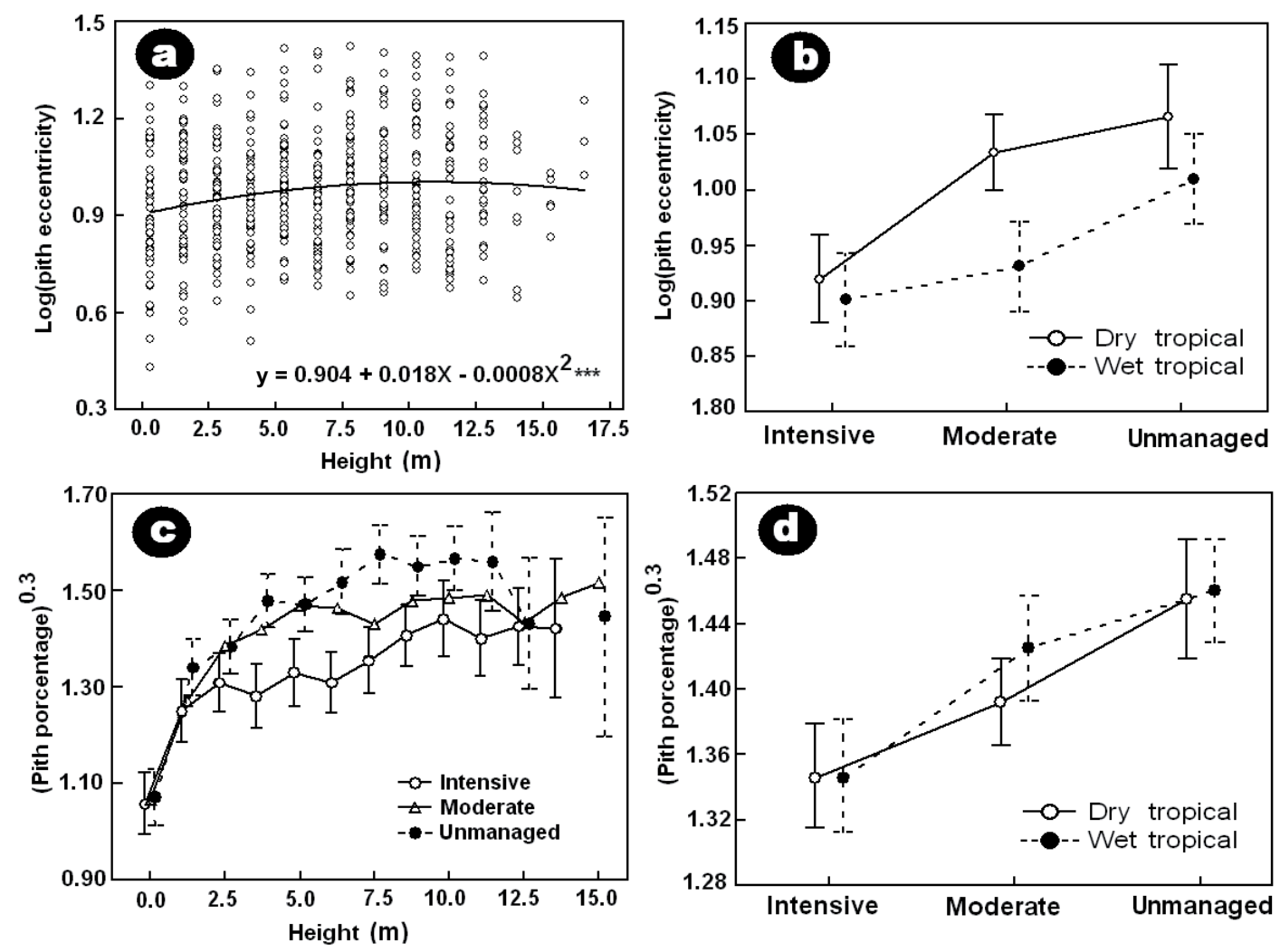

Figure 5. Variation in pith eccentricity in relation to tree height (a), effect of climate type and plantation management intensity on pith eccentricity, variation in pith percentage along tree height (c) and effect of climate type and plantation management intensity on pith percentage.

quite flat (Herrera, 1990). It is difficult to assert that in this study the influence of both wind and topography in each of the regions are the causes for the tree bole deviations, however, it is not unreasonable to expect that there are different mechanisms available to the tree to maintain verticality under different growing conditions; such conditions are regulated by growth dynamics (Cremer, 1998).

\subsection{Pith percentage}

Pith percentage ranges from 1 to 5\%. The ANOVA showed that the effects of tree height and management level in the plantations were highly significant, while climate had only a slight effect (Tab. III). With respect to tree height, percentage pith increased from the base up to a height of $5 \mathrm{~m}$ approximately, and then the remained constant with height in both the trees from unmanaged plantations and those with moderate management, unlike the trees from plantations with intensive management, where the percentage pith increased up to $10 \mathrm{~m}$ (Fig. 5c). As a result the differences between the types of management were recorded only between 3.75 and $8.75 \mathrm{~m}$ for trees from plantations under intensive management and those in plantations without any management (Fig. 5c).

In contrast, percentage pith diminished with increasing level of management (Fig. 5d). Although climate was of limited significance, as revealed by the ANOVA (Tab. III), on establishing the differences among plantations with differing levels of management, it became clear that there were no differences in percentage pith between dry and wet tropical climates for any management intensity (Fig. 5d). Pith percentage behaves in a similar way in relation to tree diameter (Fig. 5c). The variation in pith diameter also differs over tree height; from the base up to $5 \mathrm{~m}$ there is a slight increase in pith diameter, which stabilizes above this height (Fig. 3b). This relationship can be suggesting that there might be a relationship between secondary growth of tree diameter and pith diameter. Many studies report asymmetry between the tree and the internal pith characteristics (Koch et al., 1990; Skatter and Gjerdrum, 1998). This factor has a notable effect on the number of boards with pith and can cause deformations owing to its association with reaction wood, lower wood density, and decreased mechanical resistance, among other factors (Dumail and Castera, 1997; Machado and Cruz, 2005; Moya and Muñoz, 2008; Skatter and Gjerdrum, 1998).

Intensive management results in the elimination of trees with poor shape, generally those with bifurcations, twists or any kind of damage (Galloway et al., 2001) leading to an increase in tree diameter, and a decrease in percentage pith as management on the plantation increases (Fig. 5d). The management of plantations has direct consequences for the properties of wood (Gartner, 2005; Zobel and van Buijtenen, 1989) and Gmelina arborea is no exception (Moya, 2004b). 
Decreases in percentage pith lead to important benefits during sawmill processes and reduce the problems associated with pith (Koch et al., 1990).

\section{CONCLUSION}

Forest plantation produce large quantity of $\log /$ area and at same time pith parameters affects significantly the factor recovery percentage in sawmill process in Gmelina arborea. According to our results, it was demonstrated that climate growing conditions, tree height and management plantation intensity affect significantly pith parameters. So these parameters will allow the control of the diameter and eccentricity of pith. The climate factor can be less useful for controlling of pith in Costa Rica, because areas for planted trees are limited and there is not possible to choose a better place. However, climate conditions with adverse environmental conditions, such the action of wind, result in a change in the stem curvature or reaction wood production accompanied by pith eccentricity. On the other hand, tree height or management factor would be controlled for decreasing of pith diameter or eccentricity.

Lower logs of trees are characterized by highest pith eccentricity, however pith distance concentrated at $6 \mathrm{~cm}$ around geometric center of the tree. To knowing the pith variation allows us to establish sawing patterns where middle boards content the pith variation. As result we can decrease or limit the negative effects of the pith, such as reaction wood, asymmetric shrink around pith because it was concentrated in only one board. The management area associated with elimination of curvature trees, resulting straight trees in the last thinning or in final crop. Those trees are characterized by low values of percentage and eccentricity of the pith, allowing better lumber quality.

Although, it was not explored genetic control of pith parameters, it could be interesting to research genetic aspects on pith variation. Cloned plasticity trees with low pith eccentricity have the ability to adapt themselves to different growing conditions. They could decrease the effect associated to pith and increase the lumber quality as well. A combination of genetic control with management seems to be the best way to improve the pith parameters variation.

Acknowledgements: The authors wish to thank The Research ViceRectory of the Technological Institute of Costa Rica (ITCR), the Costa Rican Forestry Chambers (CCF) and the Costa Rican Ministry of Science and Technology (CONICIT- MICIT) for both their cooperation during the fieldwork and financial support. And Bianca Delfosse edited the English version of the manuscript.

\section{REFERENCES}

Akachuku A.E. and Abolarin D.A., 1989. Variations in the pith eccentricity and ring width in teak (Tectona grandis L.F.). Trees 3: 111-116.

Albert S. and Shah J.J., 1998. Early ontogeny of vascular meristem in the petiole of Gmelina arborea (Verbenaceae) and Tabebuia rosea (Bignoniaceae). Phytomorphology 48: 187-194.

Archer RR., 1986. Growth Stresses and Strains in Trees. Springer-Verlag, New York. pp. 150-151.
ASTM (American Society for Testing and Materials), 2003. Standard practice for establishing structural grades and related allowable properties for visually graded lumber D-245-00 (reproved 2002). Annual Book of ASTM Standards, Vol 04.10., Philadelphia, USA, pp. $125-158$.

Cassens D.I., 2004. Factors determining the suitability of trees and logs for the face veneer industry. In Proceedings of the 14th Central Hardwood Forest Conference. GTR-NE-316, Proceedings of a Conference held at the Ohio Agriculture Research and Development Center (OARDC), The Ohio State University, Wooster, Ohio, March $16-19$.

Clair B., Alméras T., and Sugiyama J., 2006. Compression stress in opposite wood of angiosperms: observations in chestnut, mani and poplar. Ann. For. Sci. 63: 507-510.

Constant T., Mothe F., Badia M.A., and Saint-Andre L., 2003. How to relate the standing tree shape to internal wood characteristics: proposal of an experimental method applied to poplar trees. Ann. For. Sci. 60: 371-378.

Cremer K.W., 1998. Recovering of Pinus radiata saplings from tilting and bending. Aust. For. 61: 211-219.

Dumail F. and Castera P., 1997. Transverse shrinkage in maritime pine juvenile wood. Wood Sci. Tech. 31: 251-264.

Dvorak W.S., 2004. World view of Gmelina arborea: opportunities and challenges. New For. 28: 111-126.

Galloway G., Ugalde L., and Vasquez W., 2001. Importance of density reduction in tropical plantations: Experiences in Central America. Forests Trees and Livelihoods 11: 217-232.

Gartner B., 2005. Assessing wood characteristics and wood quality in intensively managed plantations. J. For. 103: 75-77.

Herrera L., 1990. Clima y vegetación de Costa Rica. Departamento de Historia Natural, Museo Nacional de Costa Rica, 515 p.

Jane F.E., Wilson K., and White D.J., 1970. The structure of wood. Black, London, $216 \mathrm{p}$.

Kellog R.M. and Barber F.J., 1981. Stem eccentricity in coastal western hemlock. Can. J. For. Res. 11: 714-718.

Koch P., Côté Jr., Schlieter J., and Day A.C., 1990. Incidence of compression wood and stem eccentricity in lodgepole pine of North America. USDA Forest Service, Intermountain Research Station, Research paper INT-420, Ogden, USA, $42 \mathrm{p}$.

Kucera L.J. and Philipson W.R., 1977. Growth eccentricity and reaction anatomy in branchwood of Drimys einteri and five native New Zealand trees. N.Z. J. Bot. 15: 517-524.

Little S. and Mergen F., 1966. External and internal changes associated with basal-crook formation in the pith and short leaf pines. Forestry 37: 179-201.

Lundgren C., 2000. Predicting log type and knot size category using external $\log$ shape data from a $3 \mathrm{D} \log$ scanner. Scand. J. For. Res. 15: 119-126.

Machado J.S. and Cruz H.P., 2005. Within stem variation of Maritime Pine timber mechanical properties. Holz Roh- Werkst. 63: 154-159.

Manson E.G., 1985. Cause of juvenile instability of Pinus radiata in New Zealand. N.Z. For. Sci. 15: 263-280.

Mikesell J.E. and Schroeder A.C., 1980. Development of chambered pith in stems of Phytolacca americana L. (Phytolaccaceae). Am. J. Bot. 97: 111-118.

Moya R., 2004a. Wood of Gmelina arborea in Costa Rica. New For. 28: 299-317. 
Moya R., 2004b. Effect of management treatment and growing regions on wood properties of Gmelina arborea in Costa Rica, New For. 28: $325-330$.

Moya R. and Muñoz F., 2008. Wet Pockets in kiln-dried Gmelina arborea lumber. J. Trop. For. Sci. 20: 48-56.

Moya R. and Tomazello M., 2007a. Wood density and fiber dimensions of Gmelina arborea in fast growth trees in Costa Rica: relation to the growth rate. Investig. Agrar. Sist. Recur. For. 16: 267-276.

Moya R. and Tomazello M., 2007b. Relationship between anatomical features and intra-ring wood density profiles in Gmelina arborea applying X-ray densitometry. Cerne 13: 384-392.

Rune G. and Warensjö M., 2002. Basal sweep and compression wood in young Scots pine trees. Scand. J. For. Res. 17: 529-537.

Saint-André L. and Leban J.M., 2001. A model for the position and ring eccentricity in transverse sections of Norway spruce logs. Holz RohWerkst. 59: 137-144.
Singleton R., DeBell D.S., Marshall D.D., and Gartner B.L., 2003. Eccentricity and fluting in young-growth western hemlock in Oregon. West J. Appl. For. 18: 221-228.

Skatter S.H. and Gjerdrum P., 1998. Simulated yield in a sawmill using different measurement technologies, Holz Roh- Werkst. 56: 267274.

Snepthorne L. and Cochran E., 1980. Statistical methods. The Iowa State University Press, 7th ed., IOWA, USA, 615 p.

Timell T.E., 1986. Compression wood in gymnosperms, Vols. 1-3. Springer Verlag, Berlin Heidelberg, New York, 425 p.

Warensjö M. and Rune G., 2004. Stem straightness and compression wood in a 22-year-old stand of container-grown Scots pine trees. Silva Fenn. 38: 143-153.

Williamson R.W., 1975. Out-of-roundness in Douglas-fir stems. For. Sci. 21: $365-370$.

Zobel B and Van Buijtenen B., 1989. Wood variation: its causes and control. Springer Verlag, New York, 415 p. 